Article

\title{
Housefly Maggot Meal as a Potent Bioresource for Fish Feed to Facilitate Early Gonadal Development in Clarias gariepinus (Burchell,1822)
}

\author{
Johnny O. Ogunji ${ }^{1, * D}$, Stanley C. Iheanacho ${ }^{1}{ }^{(D}$, Christopher C. Mgbabu ${ }^{2}$, Nuria C. Amaechi ${ }^{3}$ and $^{-}$ \\ Onyedikachi O. C. Evulobi ${ }^{4}$ (D)
}

1 Department of Fisheries and Aquaculture, Alex Ekwueme Federal University Ndufu Alike Ebonyi State, 482131 Abakaliki, Nigeria; stanley.iheanacho@funai.edu.ng

2 Department of Applied Biology, Ebonyi State University, 482131 Abakaliki, Nigeria; revnwokwa@gmail.com

3 Department of Food Science and Technology, Abia State University, 441107 Uturu, Nigeria; chinonyeremwog@yahoo.com

4 Department of Fisheries and Aquaculture Management, Nnamdi Azikiwe University, 420211 Awka, Nigeria; oc.evulobi@unizik.edu.ng

* Correspondence: ogunjijo@yahoo.com; Tel.: +234-8067558863

check for updates

Citation: Ogunji, J.O.; Iheanacho, S.C.; Mgbabu, C.C.; Amaechi, N.C.; Evulobi, O.O.C. Housefly Maggot Meal as a Potent Bioresource for Fish Feed to Facilitate Early Gonadal Development in Clarias gariepinus (Burchell,1822). Sustainability 2021, 13, 921. https://doi.org/10.3390/ su13020921

Received: 23 November 2020

Accepted: 12 January 2021

Published: 18 January 2021

Publisher's Note: MDPI stays neutral with regard to jurisdictional claims in published maps and institutional affiliations.

Copyright: (c) 2021 by the authors. Licensee MDPI, Basel, Switzerland. This article is an open access article distributed under the terms and conditions of the Creative Commons Attribution (CC BY) license (https:/ / creativecommons.org/licenses/by/ $4.0 /)$.

\begin{abstract}
Food security is threatened by the global increase of human population, climate change, inequality of wealth distribution, the state of natural resources, peace and sustainability, among others. Aquaculture has become an important part of the food supply, hence contributing to food security. Sustainable fish production, which represents an important affordable protein supply, should therefore involve feed formulation and production techniques that are not dependent on fish meal as the protein source. It is on this basis that bioeconomy becomes very important to promote the resourceful use of biomass for feed, food, biomaterials, and bioenergy. This study presents housefly maggot meal as an efficient alternative protein source to fishmeal and a valuable bioresource. Clarias gariepinus fingerlings (male and female) were fed maggot meal supplemented diets for 24 weeks and we assessed their growth and gonadal development. The findings of this study revealed that maggot-meal-enhanced diets promoted growth and faster gonadal development in fish. Maggot meal represents a quality alternative protein source to fish meal and an excellent bioresource, which can help us attain sustainable aquaculture production.
\end{abstract}

Keywords: blue bioeconomy; food security; sustainability; aquaculture; alternative protein; bioresources; housefly maggot meal; African catfish

\section{Introduction}

The United Nations (UN) has projected a rise in world population to almost 10 billion people by 2050 [1]. Such population growth in combination with climate change effects, wealth distribution inequalities, the state of natural resources, peace and sustainability, among other factors [2], may undermine the achievement of the Sustainable Development Goals (SDGs) linked to food production, hunger, poverty and health. The UN's SDG goal 2 is facing serious setbacks due to the population increase [3]. Moreover, recent devastating natural disasters and the disease pandemic, as well as religious and political crises, have also negatively impacted food systems.

In some areas climate change is hampering crop and animal production [4], thus affecting the aquaculture sector and its potential to support food production, as aquafeed production relies on crop and animal products. The fisheries sector has recorded declines in fish catch that affect the production of fish meal for aquafeed [5,6]. The shrinking availability of fish for the aquaculture industry has led to an increase in the market price of fish meal [7], undermining the affordable protein supply. 
Thorarinsdottir et al. [8] posited that having access to feed stuffs that are safe and economical has become essential to strengthen the aquaculture industry and the development of more sustainable production practices. The high cost of fish feed is also contributing to the low productivity and limited diversity of species farmed [9]. The challenge facing the aquaculture industry is to reduce the cost of feed and the industry's environmental footprint, while maintaining product quality and value [8].

There is a need for groundbreaking solutions to produce more food and improve nutrition. This presents a serious task to researchers, who must devise ways to provide protein that can feed the growing human population while limiting the negative environmental impacts of agricultural production [10]. Furthermore, programs of action must be economically viable and environmentally sustainable [7]. To improve the sustainability of aquaculture it is important to identify feed formulations and production techniques that are not dependent on fish meal as the source of protein. Alternative protein sources will play an important role in aquaculture feed development. The "bioeconomy" in particular, the blue bioeconomy, will be paramount to the success of such initiatives.

The Danish National Bioeconomy Panel [11] defined the bioeconomy as covering the development of renewable biological resources. It also includes the conversion of resources and waste generated from them into other products. Value added to the products will give rise to materials like food for humans, feed for animals, bio-based products, and bioenergy. A fundamental mission of the bioeconomy is to ensure the security of food for a growing human population in which protein supply for humans via fish production plays a key role [3]. The bioeconomy promotes the resourceful use of biomass for feed, food, biomaterials, and bioenergy [11]. Interestingly, there has been a paradigm shift in the aquaculture industry, as more attention is now paid by researchers and industry to alternative protein sources for aquafeed production [7]. This is in a bid to provide more viable and sustainable aquaculture operations with regards to feed production [12,13]. In light of this, the blue bioeconomy remains critical to ensuring smooth and sustainable aquaculture.

The "blue bioeconomy" includes any economic activity linked to the use of renewable aquatic biological resources to create products [3]. The aquatic biomass used in developing these products can include fishery residue, shellfish, crustaceans, and algae [14]. The blue bioeconomy offers efficient and sustainable options targeted at maximizing productivity, efficient bioresource utility, and effective production cost [3]. In practice, various researchers in the field of aquaculture have reported the efficacy of many unconventional protein sources of plant and animal origin that could replace fish meal and other conventional protein sources in aquaculture diet. Some of the alternatives that have been suggested include algae meal, blood meal, poultry offal, insect meal (black solider fly, grasshopper), housefly (Musca domestica) maggot meal, cashew nut waste, Bambara nut and African yam bean $[12,13,15-17]$.

Alternative protein sources can provide solutions to problems faced by small-scale farmers such as high costs of production [18] and the resultant loss in revenue due to low farm-gate prices. The Nordic Council of Ministers [19] indicated that the use of alternative protein sources will boost local production, preserving jobs locally and generating new jobs as well. Using alternative protein sources will bring about the reduction in importation of nutrients and broadly enhance the bioeconomy. The bioeconomy is set to play a major role in the shift to cleaner and more energy-efficient production processes as we transition from a fossil fuel-based economy to one based on renewable and biological resources [20]. Alternative protein sources for humans and fish production are important in securing the food and nutrition security for the increasing world population [21]. Highlighting the need to embrace the bioeconomy, this study presents house fly maggot meal as an efficient alternative protein source and quality bioresource. We also assessed the effect of maggot meal diets on the gonadal development of African catfish (Clarias gariepinus), which belongs to the family Clariidae [22]. 
Aquaculture and catfish farming offer viable opportunities for employment and help toward poverty alleviation. Above all, the sufficient provision of aquatic meat can help to cater for the growing demand of protein, as capture fisheries are no longer sustainable [23]. A number of cultivatable catfish species have been identified: C. gariepinus, Clarias anguillaris, Heterobranchus longifilis, Heterobranchus bidorsalis, Clarias isheriensis, Clarias submarginatus, Chrysichthys nigrodigitatus, Bagrus sp., and Synodontis sp. [24]. C. gariepinus is a freshwater air-breathing aquaculture species [25], known as a prominent commercial fish cultured both within and outside tropical and subtropical regions [26,27]. The FAO [6] predicted that $62 \%$ of the overall world aquaculture production will be made up of freshwater species like carp, catfish, and tilapia by 2030. In Africa, C. gariepinus is of economic importance and is a relished aquatic food with high dressing percentage [28,29].

The maturation of fish gonads and broodstock culture are important aspects of aquaculture management and practices [30]. In fish reproduction, these factors have an impact on the broodstock efficiency and facilitate fish production. Food is nutritionally acknowledged to havea substantial effect upon the development of the gonads, fecundity, and egg and larval quality of fish. According to Idowu [31], the egg diameter of fish is indirectly influenced by environmental factors such as temperature and food availability, and large eggs have an increased proportion of yolk. The larvae produced from larger eggs are also larger and have a better chance of survival in the face of adverse environmental conditions [32].

Ogunji et al. [33] reported that the high price of fish meal in world markets has necessitated the search for substitute protein sources. Housefly maggot meal—unlike other alternative protein sources, especially plant sources—can replace up to $100 \%$ of fish meal in the diets of Nile tilapia (Oreochromis niloticus) and African catfish [33-37]. Similarly, Kroeckelet al. [38] observed that black soldierfly meal (Hermetia illucens) might be a feasible alternative protein source for the partial replacement of fish meal in juvenile turbot (Psetta maxima).

The effects of maggot meal substitution on egg development in terms of oogenesis, vitellogenesis, oocyte maturation, and ovulation have not been determined in African catfish. Since gonadal development and fecundity of fish are greatly affected by broodstock nutrition [39], we also assessed the quality of maggot meal for use in broodstock diets. Specifically, we aimed to determine the effect of housefly maggot meal (magmeal hereafter) on the gonadal development of $C$. gariepinus and the histology of developing gonads.

\section{Materials and Methods}

\subsection{Animal Care and Acclimation}

The experiment was conducted at the Department of Fisheries and Aquaculture, Ebonyi State University, Abakaliki, Nigeria. Healthy C. gariepinus fingerlings (initial mean weight $2.0 \pm 0.1 \mathrm{~g}$ and length $5.0 \pm 0.9 \mathrm{~cm}$ ) were obtained from the departmental fish culture pond. The fish were offspring of domesticated parents selected through a breeding program. The fish were acclimatized in twelve experimental concrete tanks $(676.86 \mathrm{~L}$ capacity) for seven days [40] in static water under a natural photoperiod of $12 \mathrm{~h} \mathrm{light:} 12 \mathrm{~h}$ darkness. The fish were fed commercially formulated diet (Coppens feed, Netherlands). Tanks were cleaned and culture water from a tap was partly replaced by draining every 3 days to avoid pollution resulting from feces and uneaten food. The fish were starved for 24 $h$ before the start of the feeding trial [41].

The temperature, dissolved oxygen, and $\mathrm{pH}$ of the water were measured throughout the experiment and remained relatively stable: Temperature was maintained at $26 \pm 0.2$ ${ }^{\circ} \mathrm{C}$, dissolved oxygen ranged between 6.5 and $8.0 \mathrm{mg} / \mathrm{L}$, and $\mathrm{pH}$ fluctuated between 6 and 8. No extreme values were recorded in an experimental tank.

\subsection{Experimental Diet Formulation}

The housefly maggot meal used for this study was produced using the semi-transparent larval stage of housefly ( $\mathrm{Musca}$ domestica) that grew on poultry droppings as described by 
Ogunji et al. [42]. Four experimental diets were formulated to yield a protein content of $40 \%$ on a dry matter basis. Fish meal and maggot meal were used as the major dietary protein sources (Table 1). The fish meal concentration in the test diets decreased with an increasing concentration of maggot meal at levels of 0.00 (control), $250 \mathrm{~g} \mathrm{~kg}^{-1}, 450 \mathrm{~g} \mathrm{~kg}^{-1}$, and $650 \mathrm{~g} \mathrm{~kg}^{-1}$ inclusion rate, coded as D1, D2, D3, and D4, respectively. The diet with no maggot meal (D1) served as control (Table 2). In preparing diets, all large ingredients were homogenized. Dry diet components, including vitamin and mineral mixtures, were thoroughly mixed with oil. Water was added and the feed was pelleted into sizes of $1 \mathrm{~mm}$ diameter. The mixer and pelletizer were locally fabricated. The wet pellets were dried for threedays at room temperature, packaged in an air-tight container, and stored in the refrigerator until use.

Table 1. The proximate composition (\%) of feed ingredients (mean \pm standard error).

\begin{tabular}{cccc}
\hline Proximate Components & Maggot Meal & Fish Meal & Maize \\
\hline Crude protein $(\%)$ & $44.87 \pm 0.01$ & $61.55 \pm 0.03$ & $10.91 \pm 0.03$ \\
\hline Crude fat $(\%)$ & $7.38 \pm 0.01$ & $6.76 \pm 0.01$ & $3.93 \pm 0.01$ \\
\hline Crude fiber $(\%)$ & $6.88 \pm 0.02$ & $0.56 \pm 0.01$ & $1.95 \pm 0.01$ \\
\hline Crude ash $(\%)$ & $7.95 \pm 0.02$ & $15.84 \pm 0.01$ & $1.08 \pm 0.01$ \\
\hline Moisture content $(\%)$ & $7.35 \pm 0.01$ & $5.18 \pm 0.01$ & $8.28 \pm 0.02$ \\
\hline NFE $(\%)$ & $25.57 \pm 0.01$ & $10.10 \pm 0.02$ & $84.03 \pm 0.02$ \\
\hline
\end{tabular}

Table 2. Formulation ( $\mathrm{g} \mathrm{kg}^{-1}$ feed) and proximate composition ( $\mathrm{g} \mathrm{kg}^{-1}$ dry matter) of the experimental diets used in the feeding trial.

\begin{tabular}{ccccc}
\hline \multirow{2}{*}{ Feed Ingredients $(\mathbf{g})$} & \multicolumn{4}{c}{ Diets (Inclusion Levels) } \\
\cline { 2 - 5 } & $\mathbf{D}_{\mathbf{1}}$ Control & $\mathbf{D}_{\mathbf{2}}$ & $\mathbf{D}_{\mathbf{3}}$ & $\mathbf{D}_{\mathbf{4}}$ \\
\hline Fish & 520 & 380 & 360 & 280 \\
Maggot meal & 00 & 250 & 450 & 650 \\
Maize & 430 & 320 & 140 & 20 \\
Fish oil & 30 & 30 & 30 & 30 \\
Vitamin/mineral & 20 & 20 & 20 & 20 \\
premix & & & & \\
Proximate Analysis & & & $40.78 \pm 0.05$ & $40.46 \pm 0.08$ \\
Crude protein & $40.99 \pm 0.04$ & $40.83 \pm 0.02$ & $3.96 \pm 0.01$ & $3.85 \pm 0.01$ \\
Fat & $4.42 \pm 0.01$ & $4.36 \pm 0.01$ & $4.74 \pm 0.01$ & $4.87 \pm 0.01$ \\
Fiber & $3.56 \pm 0.01$ & $3.68 \pm 0.01$ & $12.94 \pm 0.01$ & $12.86 \pm 0.01$ \\
Ash & $12.67 \pm 0.01$ & $13.03 \pm 0.01$ & $37.59 \pm 0.05$ & $37.96 \pm 0.08$ \\
NFE & $38.36 \pm 0.04$ & $38.10 \pm 0.03$ & $90.86 \pm 0.01$ & $90.78 \pm 0.01$ \\
Dry Matter & $91.57 \pm 0.01$ & $91.63 \pm 0.01$ & $17.94 \pm 0.00$ & $17.88 \pm 0.00$ \\
Energy (kJ g $\left.{ }^{-1}\right)^{3}$ & $18.31 \pm 0.00$ & $18.20 \pm 0.00$ & & \\
\hline
\end{tabular}

${ }^{1}$ Values in Proximate Analysis are mean of triplicate determination. ${ }^{2}$ NFE $=100-(\%$ crude protein $+\%$ fat $+\%$ ash $+\%$ fiber $) ;{ }^{3}$ Calculated by: crude protein $=23.9 \mathrm{~kJ} / \mathrm{g}$, crude fats $=39.8 \mathrm{~kJ} / \mathrm{g}, \mathrm{NFE}=17.6 \mathrm{~kJ} / \mathrm{g}[43]$.

\subsection{Experimental Procedure}

The fingerlings were assigned to four test diets (i.e., four groups), of which each group had 150 fingerlings. Each group was further assigned to triplicate tanks (50 fish/tank) in a randomized design. The fish were manually fed a total of $5 \%$ of body weight per day in two meals at 9:00 a.m. and 3:00 p.m. local time [34]. Fish were weighed every other week for 24 weeks and the quantity of feed was adjusted accordingly [43]. Experimental fish were inspected daily for abnormal behavior and mortality. Water quality parameters were monitored daily and maintained at optimal water quality conditions. 


\subsection{Histological Analysis}

From the start of the experiment to week 24, two fish from each tank were sampled every two weeks. The fish were dissected to obtain liver and gonads. From week 12 of the experiment, when the gonads were sighted and liver tangible, they were removed and preserved in $10 \%$ phosphate buffer formalin solution to retain the structural integrity of the cells and tissue $[44,45]$. The dealcoholized tissues were impregnated in molten paraffin wax for $3 \mathrm{~h}$. After impregnation, tissues were embedded using a disposable embedding mold and allowed to cool. Before sectioning, the embedded tissues were placed on ice. The tissues were sectioned using a Leica rotary microtome (LEICA RM-2125 AUTOMATIC) and transferred to the flattening table (hot plate) from the water bath to dry. Finally, the sections were stained using the hematoxylin eosin staining procedure described by Baker and Silverton [46]. The prepared slides were examined with a compound light microscope (Motic ${ }^{\mathrm{TM}}$, Germany) using $\times 100$ and $\times 160$ objective lenses. The photomicrographs were taken using a Motic ${ }^{\mathrm{TM}}$ 9.0-megapixel microscope camera at $\times 100$ and $\times 160$ magnification.

\subsection{Proximate Analysis}

Proximate analyses of feed samples were carried out. Protein $(\mathrm{N} \times 6.25)$ was determined by the Kjeltec System (The Kjeltec ${ }^{\mathrm{TM}} 2300$ Analyzer Unit -FOSS Analytical, Hilleroed, Denmark) and crude fat by the Soxtec System HT (Tecator) using petroleum ether. The ash content was determined by burning in a muffle furnace at $550{ }^{\circ} \mathrm{C}$ for $10 \mathrm{~h}$. Gross energy was calculated based on crude protein $=23.9 \mathrm{~kJ} \mathrm{~g}^{-1}$, crude lipids $=39.8 \mathrm{~kJ} \mathrm{~g}^{-1}$, and NFE = $17.6 \mathrm{~kJ} \mathrm{~g}^{-1}[46]$.

\subsection{Statistical and Growth Analysis}

At the end of the experiment, all fish were weighed and data were obtained from triplicate tanks. Growth performance and nutrient utilization of the experimental fish were based on the following parameters:

$$
\begin{gathered}
\text { Mean weight gain }(\mathrm{MWG})=\text { mean final weight }- \text { mean initial weight, } \\
\text { Specific growth rate }(\mathrm{SGR} \%)=\left(\mathrm{In} \mathrm{W}_{2}-\mathrm{InW}_{1} / \mathrm{T}_{2}-\mathrm{T}_{1}\right) \times 100
\end{gathered}
$$

where $W_{2}$ is the final weight of fish, $W_{1}$ is the initial weight of fish, $T_{1}$ is the beginning of the experiment (day) and $\mathrm{T}_{2}$ is the end of the experiment (day).

The gonadosomatic index (GSI) was calculated by

$$
\text { GSI }(\%)=\text { Gonad weight }(\mathrm{g}) \times 100 / \text { Body weight }(\mathrm{g}) \text {. }
$$

All biological data resulting from the feeding trial were subjected to one-way analysis of variance (ANOVA) tests. Significant differences between means were determined by Duncan's multiple range test (DMRT). Results were considered statistically significant with $p$-values of $<0.05$. Data analysis was carried out using SPSS $^{\circledR}$ for Windows (version 17). Values are expressed as the mean $\pm \mathrm{SE}$.

\section{Results}

\subsection{Composition of Experimental Diet and Growth Performance}

The growth performances of experimental fish fed maggot meal supplemented diets for 24 weeks are shown in Table 3. The experimental fish groups showed a higher body biomass than the control, but the differences in weight were not statistically significant $(p>0.05)$. The lack of significance may be due to the high standard error caused by unusually high fish growth recorded in one of the three replicates of treatment D2 and D4. However, all replicate treatments received the same attention. There was no significant difference in the SGR across all feeding groups $(p>0.05)$. 
Table 3. Growth performance and nutrient utilization of experimental fish fed maggot-meal-based diets for 24 weeks ${ }^{1, *}$.

\begin{tabular}{ccccc}
\hline Diets & $\mathbf{D}_{\mathbf{1}}(\mathbf{g})$ & $\mathbf{D}_{\mathbf{2}} \mathbf{( g )}$ & $\mathbf{D}_{\mathbf{3}} \mathbf{( g )}$ & $\mathbf{D}_{\mathbf{4}} \mathbf{( g )}$ \\
\hline Initial weight & $1.66 \pm 0.03$ & $1.69 \pm 0.00$ & $1.62 \pm 0.07$ & $1.61 \pm 0.00$ \\
Final weight $(\mathrm{g})^{*}$ & $71.23 \pm 4.42$ & $90.65 \pm 14.81$ & $87.38 \pm 1.05$ & $90.94 \pm 13.58$ \\
Mean weight gain $(\mathrm{g})^{1}$ & $69.58 \pm 4.44$ & $88.97 \pm 14.6$ & $85.76 \pm 1.11$ & $89.33 \pm 13.58$ \\
SGR \% $^{2}$ & $2.09 \pm 0.05$ & $2.20 \pm 0.09$ & $2.22 \pm 0.03$ & $2.23 \pm 0.09$ \\
\hline
\end{tabular}

${ }^{*}$ Initial number of fish per tank $=50$; Final number of fish per tank $=22-25$ (two fish were sampled each week for gonad assessment until week 24$) ;{ }^{1}$ Mean weight gain (MWG) $=$ mean final weight - mean initial weight. ${ }^{2}$ Specific growth rate $(\mathrm{SGR})=\left(\mathrm{In} \mathrm{W}_{2}-\mathrm{InW}_{1} / \mathrm{T}_{2}-\mathrm{T}_{1}\right) \times 100$.

The evaluation of the GSI started in week 12, when the gonads were first observed in the experimental fish. However, the gonads were difficult to weigh. The gonadosomatic index of male $C$. gariepinus fed maggot meal supplemented diets ranged from a mean value of $0.28 \pm 0.02$ (Diet 2, week 16) to $1.84 \pm 0.54$ (Diet 1, week 24) (Table 4). The gonadosomatic index of female fish ranged from a mean value of $2.26 \pm 0.35$ (Diet 3,week 16) to $18.48 \pm 1.57$ (Diet 3, week 24). The GSI increased in duration-dependent pattern in female and male fish. The lowest value of gonadosomatic index was observed in week 16, while the highest value was observed in week 24 . There were no significant differences $(p>0.05)$ in values of the gonadosomatic index among experimental groups.

Table 4. Mean gonadosomatic index of Clarias gariepinus fed with maggot-meal-based diets for 24 weeks.

\begin{tabular}{ccccccc}
\hline & \multicolumn{3}{c}{ Male } & \multicolumn{3}{c}{ Female } \\
\hline Diets & Week 16 & Week 20 & Week 24 & Week 16 & Week 20 & Week 24 \\
\hline D1 & $0.86 \pm 0.06$ & $1.25 \pm 0.01$ & $1.84 \pm 0.54$ & $3.51 \pm 1.38$ & $8.01 \pm 1.35$ & $15.25 \pm 2.26$ \\
D2 & $0.28 \pm 0.02$ & $0.92 \pm 0.26$ & $1.32 \pm 0.18$ & $3.47 \pm 0.90$ & $11.50 \pm 1.84$ & $18.05 \pm 2.40$ \\
D3 & $0.31 \pm 0.10$ & $0.93 \pm 0.21$ & $1.68 \pm 0.44$ & $2.26 \pm 0.35$ & $7.84 \pm 2.01$ & $18.48 \pm 1.57$ \\
D4 & $0.42 \pm 0.10$ & $0.60 \pm 0.20$ & $1.38 \pm 0.02$ & $3.11 \pm 0.10$ & $8.08 \pm 1.64$ & $18.10 \pm 0.70$ \\
\hline
\end{tabular}

Phases (in weeks) of Oocyte development (Oogenesis)

Table 5 shows the stages of gonadal development of the samples in different treatment groups. The gonads were in the resting stage from the outset of the experiment to week 12 , when dark ribbon-like features were observed in the dorsal lateral lining of the peritoneal cavity of the sampled fish. This is the position where the gonads were expected to be located. The sexes of the fish were unidentified. By week 16, the sex of the fish fed experimental diets was determined histologically. Among the control group (D1), the female fish samples (mean weight $\pm \mathrm{SE} ; 35.16 \pm 7.30 \mathrm{~g}$ ) were clearly distinguished morphologically and were histologically observed to be in chromatin nucleolar stage (Table 5 and Figure 1a).However, fish groups fed diet $\mathrm{D} 2$ (mean weight $\pm \mathrm{SE} ; 47.08 \pm 4.93 \mathrm{~g}$ ) and $\mathrm{D} 3$ (mean weight $\pm \mathrm{SE}$; $42.36 \pm 0.83 \mathrm{~g}$ ) were in the perinucleolar stage (Table 4, Figure $1 \mathrm{~b}, \mathrm{c}$ ) and those fed diet D4 (mean weight $\pm \mathrm{SE} ; 49.56 \pm 6.76 \mathrm{~g}$ ), which contained the highest proportion of maggot meal $(65 \%)$, were observed to be in cortical alveoli stage (Figure 1d).

In week 20, the gonads of the fish fed with D1 (control diet) (mean weight $\pm \mathrm{SE}$; $48.45 \pm 8.2 \mathrm{~g}$ ) were observed to be in the perinucleolar stage (Table 5 and Figure 2a), those fed with D2 (mean weight $\pm \mathrm{SE} ; 48.84 \pm 9.11 \mathrm{~g}$ ) were in the cortical alveoli stage (Figure $2 \mathrm{~b}$ ), and those fed D3 (mean weight \pm SE; $59.27 \pm 1.49 \mathrm{~g}$ ) and D4 (mean weight $\pm \mathrm{SE}$; $62.26 \pm 8.56 \mathrm{~g}$ ) were in the vitellogenic stage (Figure $2 \mathrm{c}, \mathrm{d}$ ). This trend was followed until the end of the feeding trial (week 24). At this time, the gonads of the fish (mean weight $\pm \mathrm{SE} ; 71.23 \pm 4.41 \mathrm{~g}$ ) fed with diet D1 had histologically developed to the vitellogenic stage (Figure 3a), but those that were fed diet D2 (mean weight \pm SE; $90.65 \pm 14.81 \mathrm{~g}$ ) were observed to be in the oocyte maturation/hydration stages (Figure 3b). Fish fed with diets 
D3 (mean weight \pm SE; $87.38 \pm 1.04 \mathrm{~g}$ ) and D4 (mean weight \pm SE; $90.94 \pm 13.58 \mathrm{~g}$ ) were both observed to be in the ripe stage (Figure $3 c, d$ ), indicating their faster development.

Table 5. Stages of gonad development of C. gariepinus females fed maggot-meal-based diet.

\begin{tabular}{llllllllll}
\hline Diet & & \multicolumn{7}{c}{ Time (Weeks) } \\
\hline & $\mathbf{2}$ & $\mathbf{4}$ & $\mathbf{6}$ & $\mathbf{8}$ & $\mathbf{1 0}$ & $\mathbf{1 2}$ & $\mathbf{1 6}$ & $\mathbf{2 0}$ & $\mathbf{2 4}$ \\
\hline $\mathrm{D} 1$ & $\mathrm{R}$ & $\mathrm{R}$ & $\mathrm{R}$ & $\mathrm{R}$ & $\mathrm{R}$ & $\mathrm{R}$ & $\mathrm{A}$ & $\mathrm{B}$ & $\mathrm{D}$ \\
$\mathrm{D} 2$ & $\mathrm{R}$ & $\mathrm{R}$ & $\mathrm{R}$ & $\mathrm{R}$ & $\mathrm{R}$ & $\mathrm{R}$ & $\mathrm{B}$ & $\mathrm{C}$ & $\mathrm{E}$ \\
$\mathrm{D} 3$ & $\mathrm{R}$ & $\mathrm{R}$ & $\mathrm{R}$ & $\mathrm{R}$ & $\mathrm{R}$ & $\mathrm{R}$ & $\mathrm{B}$ & $\mathrm{D}$ & $\mathrm{F}$ \\
$\mathrm{D} 4$ & $\mathrm{R}$ & $\mathrm{R}$ & $\mathrm{R}$ & $\mathrm{R}$ & $\mathrm{R}$ & $\mathrm{R}$ & $\mathrm{C}$ & $\mathrm{D}$ & $\mathrm{F}$ \\
\hline
\end{tabular}

$\mathrm{R}=$ Resting period; $\mathrm{A}=$ Chromatin nucleolar stage; $\mathrm{B}=$ Perinucleolar stage; $\mathrm{C}=$ Cortical alveolar stage; $\mathrm{D}=$ Vitel logenic stage; $\mathrm{E}=$ Oocyte maturation/hydration; $\mathrm{F}=$ Ripe stage.

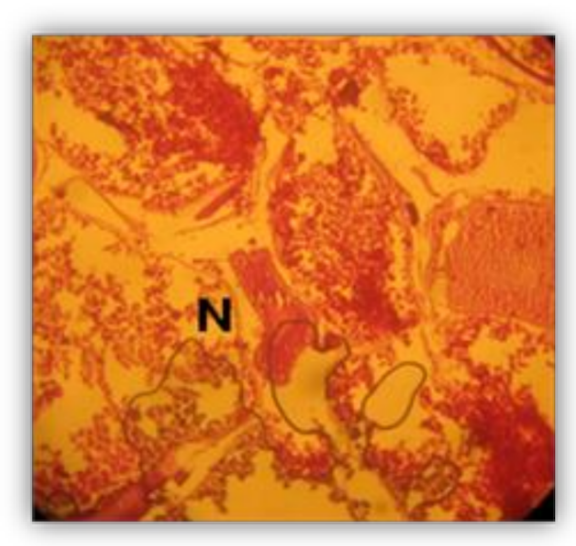

(a)

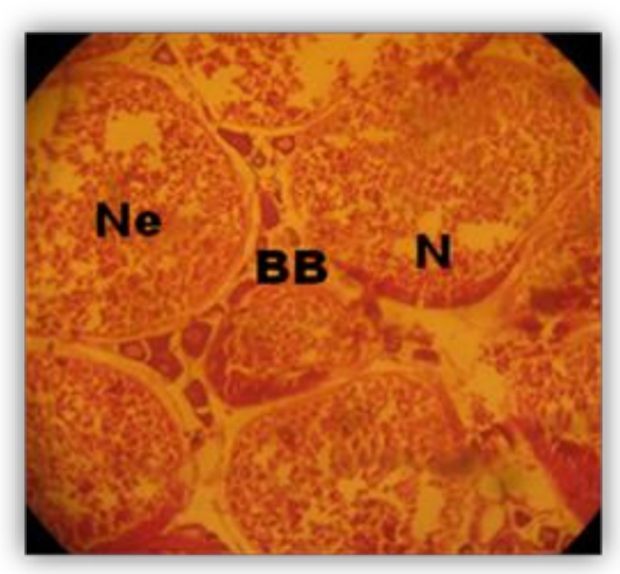

(c)

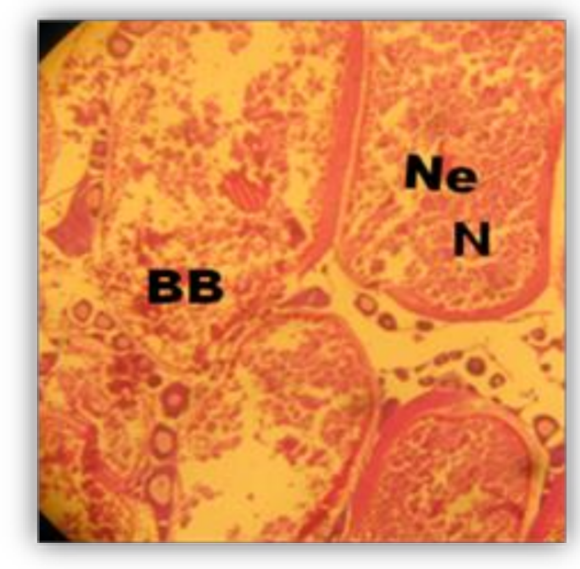

(b)

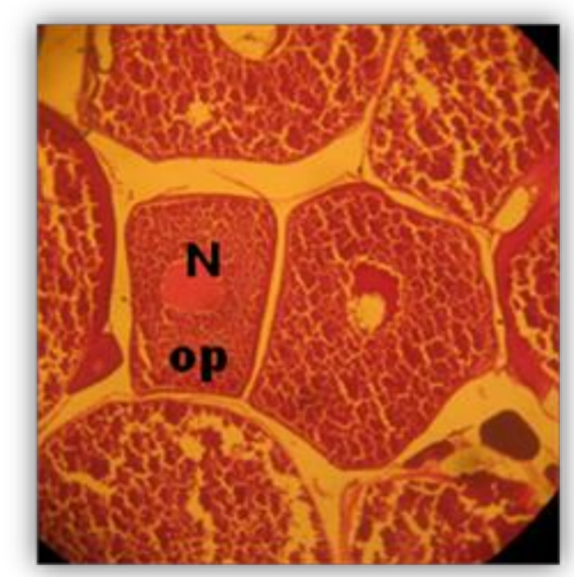

(d)

Figure 1. Female gonads of the experimental fish at week 16. (a) Diet 1, chromatin nucleolar stage ( $\left.\mathrm{St}_{1}\right)$, large nucleus in central position. $\mathrm{N}-$ nucleus, $100 \times$. (b) Diet 2, perinucleolar stage $\left(\mathrm{St}_{2}\right)$. Nucleus increased in size and number of nucleoli increased. N-nucleus, NE-nucleoli, BB-Balbiani bodies, 100×. (c) Diet 3, perinucleolar stage $\left(\mathrm{St}_{2}\right)$. Nucleus increased in size and number of nucleoli increased. N-nucleus, NE-nucleoli, BB-Balbiani bodies, 100×. (d) Diet 4, oocyte cortical vesicles were detected for the first time, i.e., spherical structures that appeared at random at various depths in the ooplasm. $\mathrm{N}$-nucleus, $\mathrm{OP}$-ooplasm, $100 \times$. 


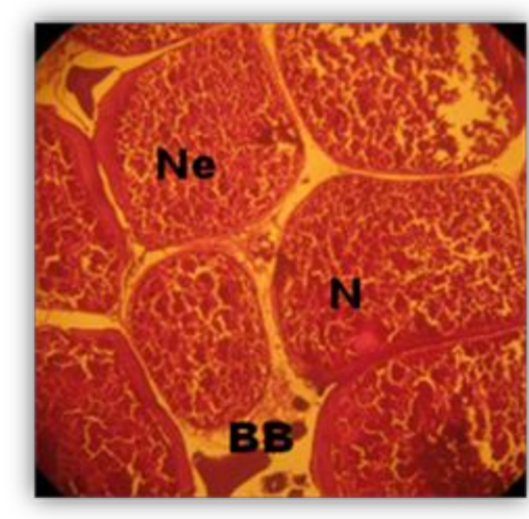

(a)

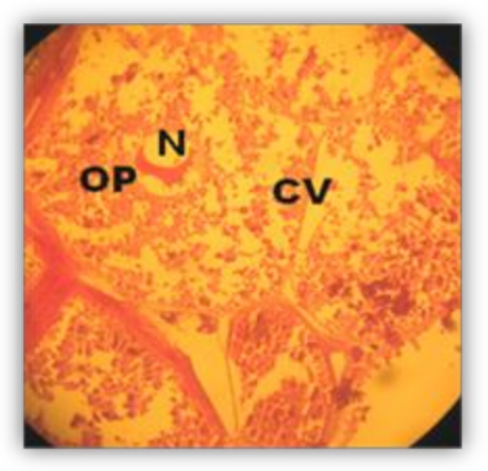

(c)

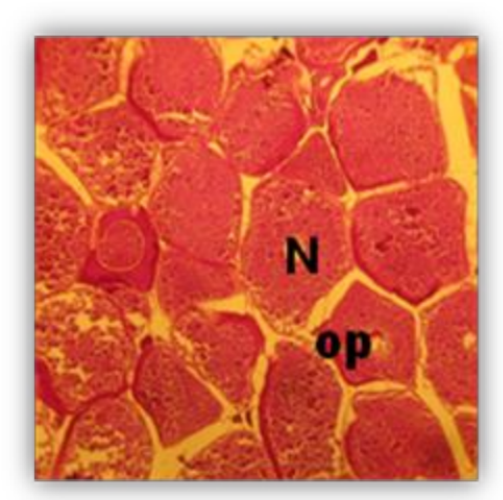

(b)

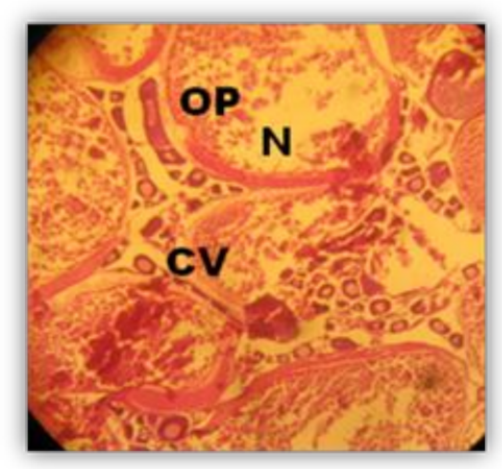

(d)

Figure 2. Female gonads of the experimental fish at week 20. (a) Diet 1, perinucleolar stage $\left(\mathrm{St}_{2}\right)$. Nucleus increased in size and number of nucleoli increased. N-nucleus, NE-nucleoli, BB-Balbiani bodies, 100×. (b) Diet 2, oocyte cortical vesicles were detected for the first time in spherical structures that appeared at random at various depths in the ooplasm. $\mathrm{N}$-nucleus, $\mathrm{OP}$-ooplasm, $160 \times$. (c) Diet 3, $\mathrm{St}_{4}$ oocyte. The nucleus consisted of many nucleoli that continued to grow, becoming irregular in shape. $\mathrm{N}$-nucleus, $\mathrm{OP}$-ooplasm, $\mathrm{CV}-$ cytoplasmic vesicle, 100×. (d) Diet4, St ${ }_{4}$ oocyte. The nucleus consisted of many nucleoli that continued to grow, becoming irregular in shape. N-nucleus, OP-ooplasm, CV—cytoplasmic vesicle, $100 \times$.

\subsection{Phases of Male Gonad Development (Spermatogenesis)}

The stages of male gonad development of the experimental fish fed with maggotmeal supplemented diets are presented in Table 6. Five stages of gonadal development in C. gariepinus were observed from samples taken from the anterior parts of the gonads. There was no observable feature in the position of the dorsal lateral lining of the peritoneal cavity where the gonad is expected to be located from the outset of the feeding trial until week 12 (fish mean weight \pm SE, $29.17 \pm 5.6 \mathrm{~g}$ ). However, in week 16, the gonads of all the fish were in the spermatogonia stage (Table 5; Figure $4 \mathrm{a}-\mathrm{c}$; fish mean weight \pm SE: $\mathrm{D} 1-35.16 \pm 7.30 \mathrm{~g} ; \mathrm{D} 2-47.08 \pm 4.93 \mathrm{~g} ; \mathrm{D} 3-42.36 \pm 0.83 \mathrm{~g})$. The gonads of fish fed with diet D4 (mean weight $\pm \mathrm{SE}, 49.56 \pm 6.76 \mathrm{~g}$ ) had advanced to the stage of primary spermatocytes stage (Table 5; Figure $4 \mathrm{~d}$ ). The gonads of the male fish fed with diet D1 (mean weight \pm SE, $48.45 \pm 8.2 \mathrm{~g}$ ) and D2 (mean weight \pm SE, $48.84 \pm 9.11 \mathrm{~g}$ ) were first observed histologically to be in primary spermatocytes in week 20 (Figure 5a,b), those fed diet D3 (mean weight \pm SE, $59.27 \pm 1.49 \mathrm{~g}$ ) and D4 (mean weight \pm SE, $62.26 \pm 8.56 \mathrm{~g}$ ) had gonads developed to the secondary spermatocytes stage (Figure $5 \mathrm{c}$ ) and spermatids stage (Figure 5d), respectively. 


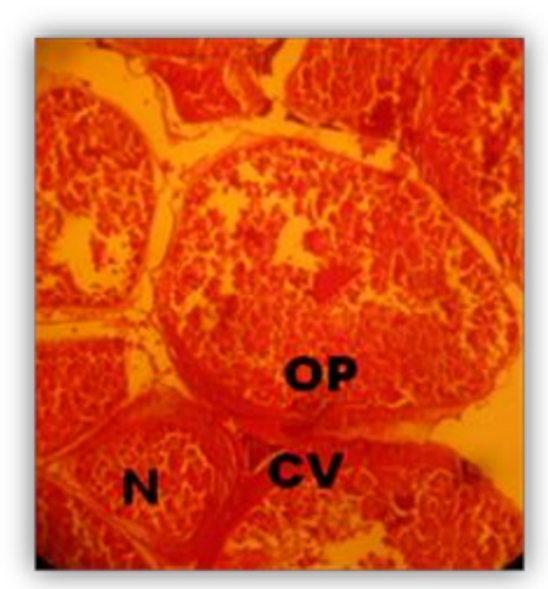

(a)

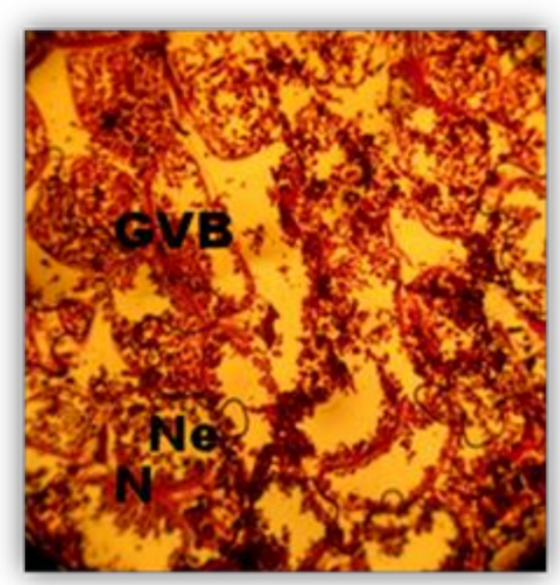

(c)

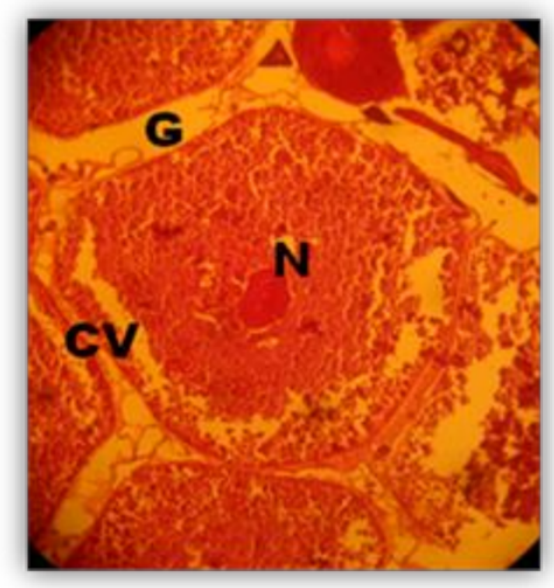

(b)

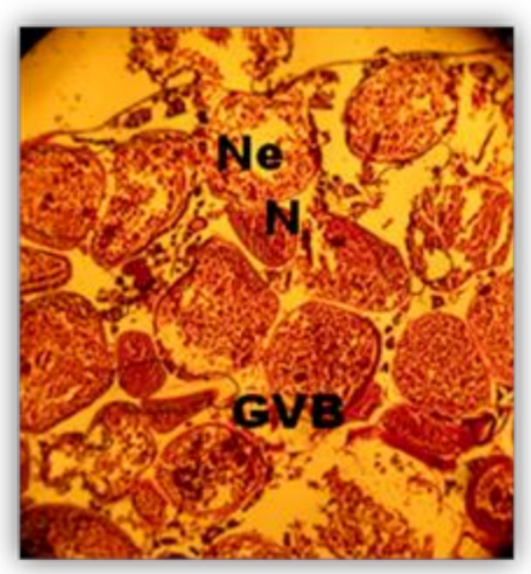

(d)

Figure 3. Female gonads of the experimental fish at week 24. (a) Diet 1, St ${ }_{4}$ oocyte. The nucleus consisted of many nucleoli and continued to enlarge, becoming very irregular in shape. $\mathrm{N}$-nucleus, $\mathrm{OP}$-ooplasm, $\mathrm{CV}$-cytoplasmic vesicle, $100 \times$. (b) Diet 2, St 5 oocytes. Yolk granules were first detected between vacuoles and later in the cytoplasm. The nucleus showed a significant number of projections into the cytoplasm. The development of the egg shell was completed with the zona radiata and vitellin membrane. $\mathrm{N}$-nucleus, $\mathrm{CV}$-cytoplasmic vesicle, G—granulose, 100×. (c) Diet 3, St 6 oocytes. Nucleus migrated to the animal pole where it remained, but the nuclear membrane disintegrated. Nucleus similar in size, but nucleoli were reduced in number compared to the previous stage $\left(\mathrm{St}_{5}\right)$. After the germinal vesicle breakdown, the oocytes ovulated into the ovarian lumen. N-nucleus, Ne-Nucleoli, GVB-germinal vesicle breakdown, 100×. (d) Diet 4, St 6 oocytes. Nucleus migrated to the animal pole where it remained, but the nuclear membrane disintegrated. Nucleus similar in size, but nucleoli were reduced in number compared to previous stage $\left(\mathrm{St}_{5}\right)$. After the germinal vesicle breakdown, the oocytes ovulated into the ovarian lumen. $\mathrm{N}$-nucleus, $\mathrm{Ne}-\mathrm{Nucleoli}$, GVB-germinal vesicle breakdown, $160 \times$.

Table 6. Stages of male gonads of C. gariepinus fed a maggot-meal-based diet.

\begin{tabular}{llllllllll}
\hline Diet & & \multicolumn{7}{c}{ Time (Weeks) } \\
\hline & $\mathbf{2}$ & $\mathbf{4}$ & $\mathbf{6}$ & $\mathbf{8}$ & $\mathbf{1 0}$ & $\mathbf{1 2}$ & $\mathbf{1 6}$ & $\mathbf{2 0}$ & $\mathbf{2 4}$ \\
\hline $\mathrm{D} 1$ & $\mathrm{R}$ & $\mathrm{R}$ & $\mathrm{R}$ & $\mathrm{R}$ & $\mathrm{R}$ & $\mathrm{R}$ & $\mathrm{A}$ & $\mathrm{B}$ & $\mathrm{C}$ \\
$\mathrm{D} 2$ & $\mathrm{R}$ & $\mathrm{R}$ & $\mathrm{R}$ & $\mathrm{R}$ & $\mathrm{R}$ & $\mathrm{R}$ & $\mathrm{A}$ & $\mathrm{B}$ & $\mathrm{C}$ \\
$\mathrm{D} 3$ & $\mathrm{R}$ & $\mathrm{R}$ & $\mathrm{R}$ & $\mathrm{R}$ & $\mathrm{R}$ & $\mathrm{R}$ & $\mathrm{A}$ & $\mathrm{C}$ & $\mathrm{D}$ \\
$\mathrm{D} 4$ & $\mathrm{R}$ & $\mathrm{R}$ & $\mathrm{R}$ & $\mathrm{R}$ & $\mathrm{R}$ & $\mathrm{R}$ & $\mathrm{B}$ & $\mathrm{D}$ & $\mathrm{E}$ \\
\hline
\end{tabular}

$\mathrm{R}=$ Resting period; $\mathrm{A}=$ Spermatogenia; $\mathrm{B}=$ Primary spermatocytes; $\mathrm{C}=$ Secondary spermatocytes; $\mathrm{D}=$ Spermatids $\mathrm{E}=$ Spermatozoa 


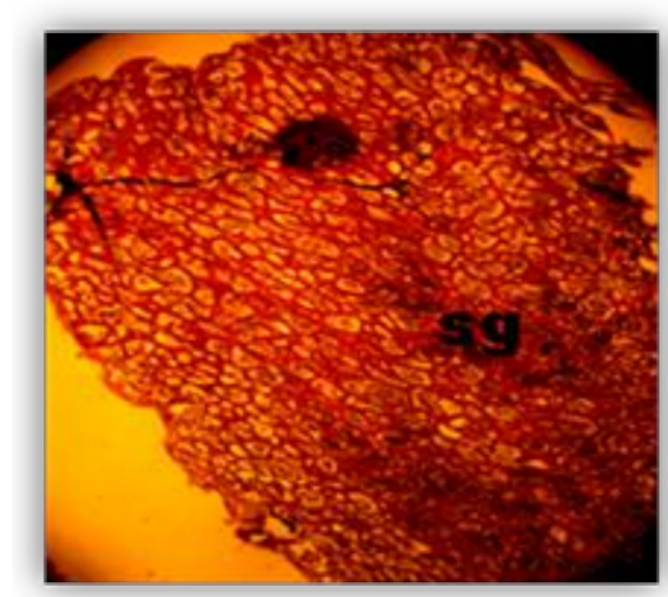

(a)

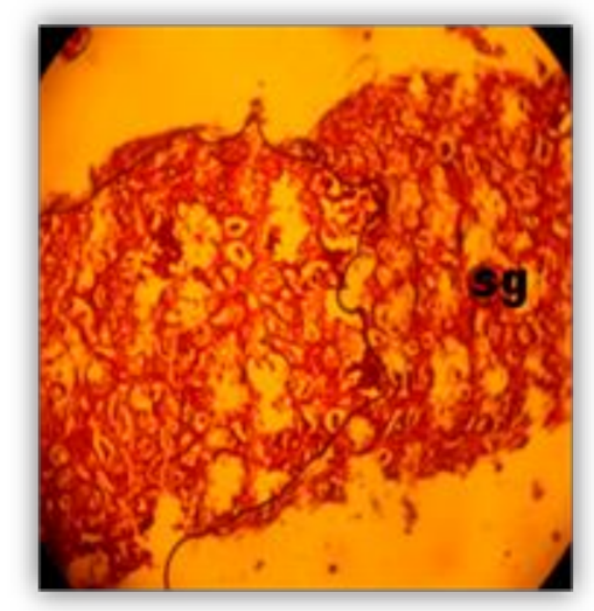

(c)

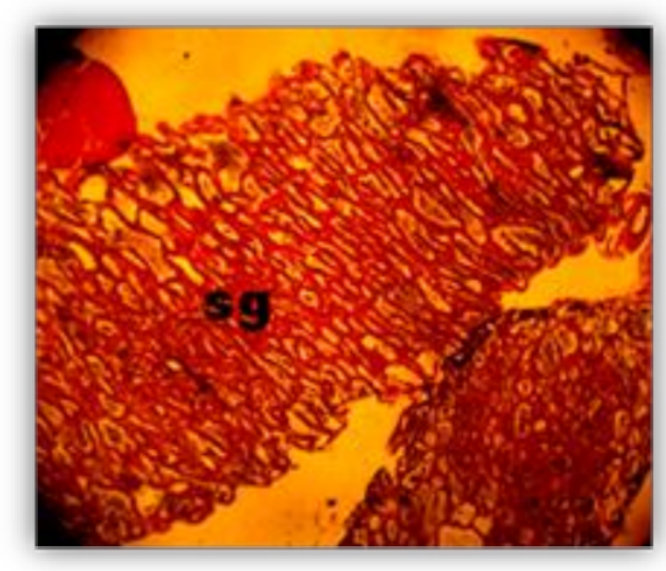

(b)

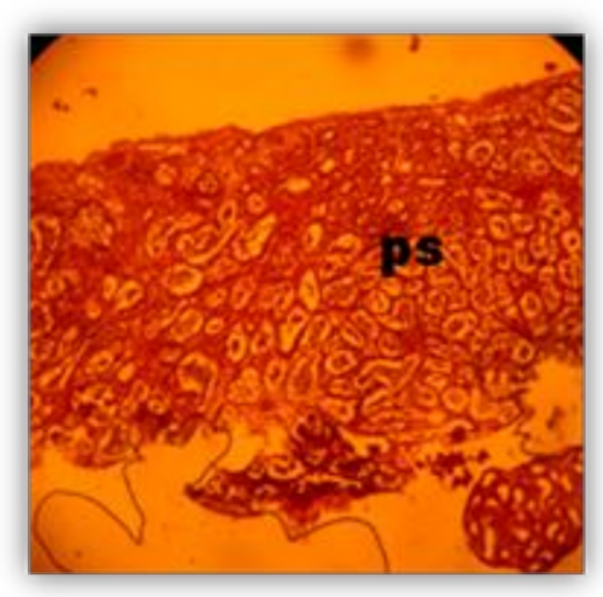

(d)

Figure 4. Male gonads of the experimental fish at week 16. (a) Diet 1, spermatogonia stage (St $\left.t_{1}\right)$. The nucleolus was large and lay close to the center of the nucleus. Sg-spermatogonia, $160 \times$. (b) Diet 2, spermatogonia stage $\left(\mathrm{St}_{1}\right)$. The nucleolus was large and lay close to the center of the nucleus. Sg-spermatogonia, 160×. (c) Diet 3, spermatogonia stage $\left(\mathrm{St}_{1}\right)$. The nucleolus was large and lay close to the center of the nucleus. Sg-spermatogonia, 160×. (d) Diet 4 , primary spermatocytes $\left(\mathrm{St}_{2}\right)$ were smaller than the spermatogonial cells, spherical and presented as small groups (nests). Ps-primary spermatocytes, $160 \times$.

In week 24, the fish fed diet D1 (mean weight $\pm \mathrm{SE}, 71.23 \pm 4.41 \mathrm{~g}$ ) and D2 (mean weight $\pm \mathrm{SE}, 90.65 \pm 14.81 \mathrm{~g}$ ) had gonads developed to the secondary spermatocytes stage (Figure 5a,b), while fish fed diet D3 (mean weight $\pm \mathrm{SE}, 87.38 \pm 1.04 \mathrm{~g}$ ) and D4 (mean weight $\pm \mathrm{SE}, 90.94 \pm 13.58 \mathrm{~g}$ ) had gonads that were developed to spermatids and rupture-free spermatozoa (Figure $5 c, d$ ), respectively. The gonads in the free spermatozoa stage appeared milky at the serrated edge of the testes. 


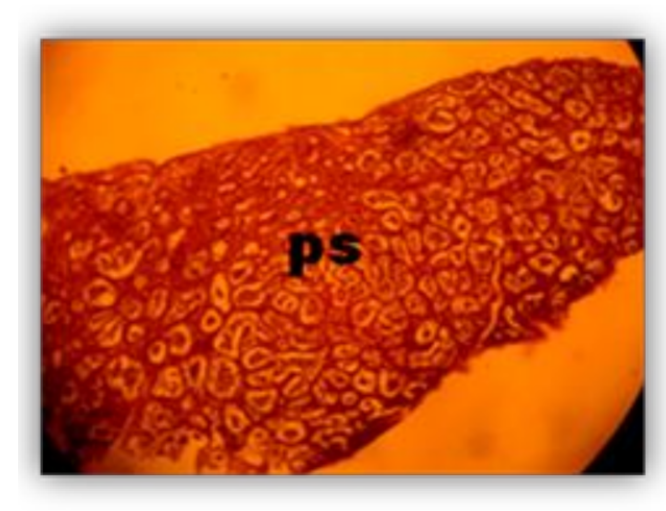

(a)

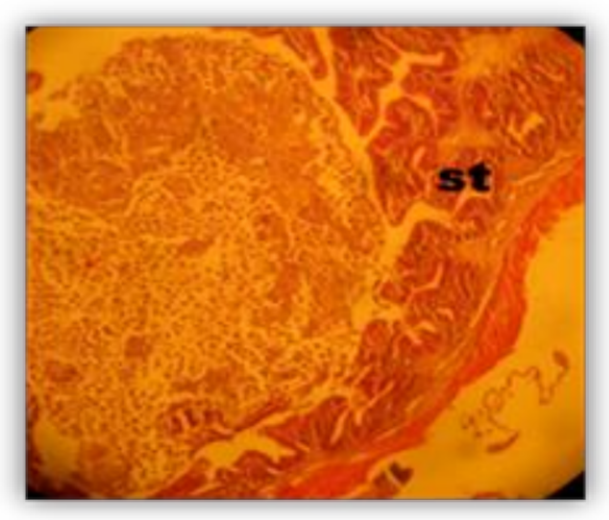

(c)

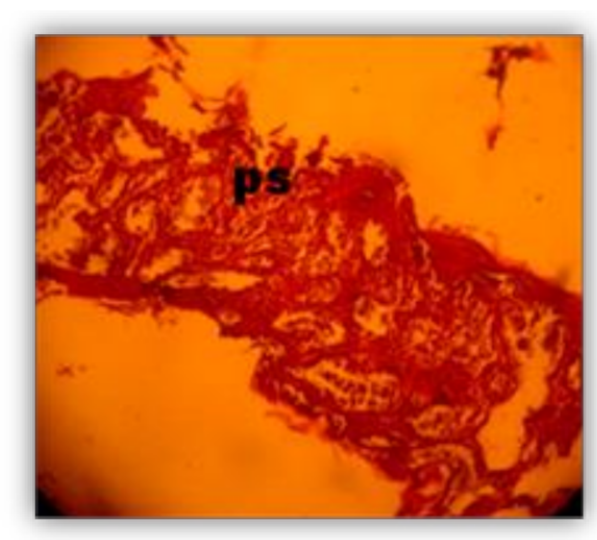

(b)

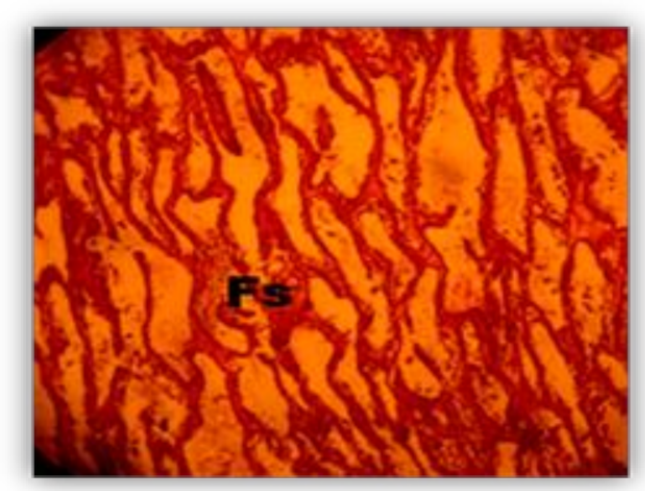

(d)

Figure 5. Male gonads of the experimental fish at week 20. (a) Diet 1, primary spermatocytes $\left(\mathrm{St}_{2}\right)$ were smaller than the spermatogonial cells, spherical, and presented as small groups (nests). Ps—primary spermatocytes, 160×. (b) Diet 2, primary spermatocytes $\left(\mathrm{St}_{2}\right)$ were smaller than the spermatogonial cells, spherical, and presented as small groups (nests). Ps-primary spermatocytes, $160 \times$. (c) Diet 3, secondary spermatocytes $\left(\mathrm{St}_{3}\right)$ morphologically similar to primary spermatocytes and more basophilic. Nucleus not clearly detected. St—spermatids, $100 \times$. (d) Diet 4, spermatids $\left(\mathrm{St}_{4}\right)$. St $\mathrm{St}_{3}$ continued meiotic division to produce spermatids. They were smaller than the secondary spermatocytes, irregular in shape and very strongly basophilic. Fs—-free spermatozoa, 100×.

\section{Discussion}

The crude protein content of the diets used in this study $(40.79 \pm 0.41 \%)$ is comparable to values reported previously. The FAO [47] reported that the propensity of C. gariepinus toward carnivorous feeding habits means they require a relatively high dietary protein intake, in the order of 40-50\% crude protein on a dry weight basis. Ali and Jauncey [48] reported that C. gariepinus fed with $35-40 \%$ protein diets displayed higher growth rates than those fed with low percentages of protein. Although the crude fat values used were lower than values reported by [49], they were within the values recommended by Alegbeleye et al. [50].

The growth performance of fish fed a maggot meal supplemented diet (D2-D4) was apparently increased, although results were not statistically significant. The SGR and MWG were not significantly different from the control; however, the highest values of SGR and MWG were recorded among fish fed Diet 4, which had the highest proportion of maggot meal in the diet. The SGR values fall within the range for similar species fed animal- and plant-based experimental diets that enhanced the development of the gonads [51]. The results of this study corroborate previous observations that maggot meal, like other animal protein sources, is well accepted and utilized by the fish [36,52].

It has been suggested that the strong growth and nutrient utilization capacity of fish fed a maggot meal supplemented diet stems from its high biological value (i.e., nutrient composition) [49]. Similarly, working with another insect larvae, Kroeckel et al. [38] 
reported that the incorporation of black soldierfly meal protein in the diet of juvenile turbot (Psetta maxima) is a feasible alternative protein source for the partial replacement of fish meal. Renna et al. [53] observed that partially defatted Hermetia illucens larvae can be included up to $40 \%$ as a feed ingredient in trout diets without impacting survival, growth performance, condition factors, somatic indices, dorsal fillet physical quality parameters, and intestinal morphology of the fish.

Our study is one of few that have assessed the effect of insect meal diets on gonadal development. The gonadosomatic index (GSI), an index of gonad size relative to fish size, is a good indicator of gonadal development in fish [54]. The GSI was higher in fish fed the maggot meal diet compared with the control diet, although there were no statistically significant differences among the feeding groups. In addition, The GSI also increased with increase in the period of feeding trial. These values were similar to those reported for C. gariepinus by Ekanem et al. [50]. In another study, Al-Deghayem et al. [55] reported the lowest GSI values for male C. gariepinus $(0.282 \pm 0.13)$ and the highest GSI result for females $(17.266 \pm 6.89)$. Mature gonads were histologically observed when the mean gonadosomatic index of the female experimental fish was $18.05 \pm 2.40$ and the ripe eggs were observed when the gonadosomatic index of the female experimental fish was $18.10 \pm 0.70$. GSI values for males in this study were lower than in the females. Hashmi et al. [54] found that GSI varies with individuals of the same species and that values for females are usually higher than males of the same size because ovaries are larger than testes.

In this study, we assessed the development of the gonads of C. gariepinus fingerlings fed maggot meal supplemented diets for six months. The gonads developed in line with changes that were reported for catfish and some other teleosts [56-60]. The oocyte developmental stages observed were the chromatin nucleolar, perinucleolar, cortical alveolar, vitellogenic, and maturation/hydration stages. The five male developmental stages detected were spermatogonia, primary spermatocytes, secondary spermatocytes, spermatids, and spermatozoa. Previous studies reported that the oogonia of C. gariepinus proliferated and turned into primary oocytes, which subsequently grew within the follicles, formed cortical alveoli, entered vitellogenesis, underwent maturation/hydration and finally ovulated $[31,39]$. In this study, the observed changes were similar to those reported for teleosts [61,62], although ovulation was not observed at the end of this study. This may have been because the feeding trial began with fingerlings and the experiment lasted for 24 weeks (i.e., six months). The period of the feeding trial was shorter than the 12 months adopted by Çek and Yilmaz [63].

On week 12 of the experiment, when the average weight of fish was $29.17 \pm 1.60 \mathrm{~g}$, the male and female gonads appeared as ribbon-like structures. These structures were attached to the dorsal lateral lining of the peritoneal cavity. Such thread-like structures are undifferentiated gonads that can finally form either male or female gonads [63]. This marks the beginning of the development of the gonads in C. gariepinus. Ogunji and Rahe [64] reported that at the end of larval development of the African catfish (H. longifilis) the gonads were not developed. In this study we found that African catfish gonads may begin development after 12 weeks.

Faster gonadal development was observed in fish groups fed high dietary maggot meal inclusion levels (Tables 5 and 6 and Figures 1-5). It is possible that the good nutrient profile of maggot meal [49] may have played a role in making the experimental diets suitable for feeding C. gariepinus broodstock. Indeed, Bromage [39] reported that gonadal development and fecundity in fish are greatly affected by broodstock nutrition in several species. The ovaries were in the resting stage from onset of the experiment until week 12 (i.e., three months into the feeding trial). The gonads of fish fed diet D1 developed to chromatin nucleolar stage between week 12 and 16, while those fed diets D2 and D3 were already developed to the perinucleolar stage, and fish fed with diet D4 were developed to the cortical alveoli stage.Guraya [65] reported that sex differentiation occurs when the newly formed ovary is first distinguishable. 
The genital papillae were observed in males at week 16 of the experiment when the weight of the fish ranged from 35.16-49.56 g. The fish fed with diets D1, D2, and D3 were observed to have gonads that were developed to the spermatogonia stage (Figure $4 \mathrm{a}-\mathrm{c}$ ), while fish fed diet D4, which contained the highest proportion of maggot meal, already had gonads developed to primary spermatocytes (Figure $4 \mathrm{~d}$ ). This represents a shorter rearing period than the 12 months of rearing suggested by Gupta [61]. In week 24, fish fed diets D1 (control) and D2 were both observed to be in the secondary spermatocytes stage, while those fed diet D3 were in the spermatids stage. It is important to note that free spermatozoa were first observed in fish fed with diet D4. This was detected when the fish had a mean weight of $90.94 \pm 13.58 \mathrm{~g}$. Schulz et al. [66] stated that maturity is related to age in C. gariepinus, but in this study we observed that maturity was more related to size and diet rather than age, in accordance with the findings of [64], in which it was reported that complete metamorphosis of $H$. longifilis is determined by the size rather than the age of larvae.

\section{Conclusions}

Food production systems are reported to be negatively impacted by the global human population increase, climate change, devastating natural disasters, disease pandemics, and religious and political crises [2]. As such, there is a need to support the achievement of the Sustainable Development Goals, especially SDG goal 2, and combat any setbacks in terms of food production and accessibility of affordable protein. Aquaculture is an important component of food security [18] and has attracted increased research attention.

To realize more sustainable aquaculture that can provide a nutritionally adequate and relatively inexpensive and highly accessible protein supply, feed formulation and production techniques must be improved. The reliance on fish meal as a protein source for feed production should change and the use of alternative protein sources should be encouraged. The bioeconomy will play a crucial role in this process. While the bioeconomy promotes the resourceful use of biomass for feed, food, biomaterials, and bioenergy, the blue bioeconomy is aimed at any economic activity linked to the use of renewable aquatic biological resources to create products. In this study, maggot meal supplemented diets resulted in increased growth rates, albeit statistically non-significant. The development of the gonads in experimental fish fed maggot meal supplemented diets was also recorded earlier than in the control. These results suggest that maggot meal is a potentially important feedstuff in broodstock nutrition, which can help to improve catfish production.

Interestingly, maggot meal has previously been established to be a quality alternative protein source. Using this feedstuff to facilitate earlier maturation of broodstock (before the established one year of maturity as reported for African catfish) [67] is important for more efficient fish production.

Maggot meal can be recommended as a suitable alternative protein source for supplementing fish meal in the diet of $C$. gariepinus broodstock, thus bringing aboutan improvement of fish seed development.

Author Contributions: Conceptualization, J.O.O.; methodology, J.O.O. and C.C.M.; software, S.C.I. and J.O.O.; validation, C.C.M., N.C.A. and O.O.C.E.; formal analysis, J.O.O., C.C.M. and S.C.I.; investigation, C.C.M. and J.O.O.; resources, J.O.O., C.C.M., S.C.I.; N.C.A. and O.O.C.E.; data curation, J.O.O., and S.C.I.; writing-original draft preparation, J.O.O.; writing-review and editing, J.O.O., C.C.M., S.C.I.; N.C.A. and O.O.C.E.; visualization, J.O.O. and C.C.M.; supervision, J.O.O. All authors have read and agreed to the publisher version of the manuscript.

Funding: This research received no external funding.

Informed Consent Statement: Not applicable for studies.

Acknowledgments: The authors are grateful to International Consortium on Applied Bioeconomy Research (ICABR) for providing a grant to cover the publication fee. The authors are also thanking V.C. Ogunji, Oluchi Iheanacho and Ven Oganezi for their support. Victoria David of University of Bradford, UK, is appreciated initially proof-reading the manuscript. 
Conflicts of Interest: The authors declare that they have no conflict of interest.

Ethical Approval: All applicable international, national, and/or institutional guidelines for the care and use of animals were followed by the authors.

\section{References}

1. Fiore, G. Farming and Food Security: An Assessment of Animal Production and Environmental Impact; EUR 28792 EN; Publications Office of the European Union: Luxembourg, 2017; ISBN 978-92-79-73832-6. [CrossRef]

2. FAO-Food and Agriculture Organization. The Future of Food and Agriculture: Alternative Pathways to 2050. 2018. Available online: http:/ / www.fao.org/3/CA1553EN/ca1553en.pdf (accessed on 22 November 2020).

3. EUMOFA—European Market Observatory for Fisheries and Aquaculture Products Union. Blue Bioeconomy: Situation Report and Perspective. 2018, pp. 1-144. Available online: https://www.eumofa.eu/documents/20178/84590/Blue+bioeconomy_Final.pdf (accessed on 15 January 2021). [CrossRef]

4. Onyeneke, R.U.; Igberi, C.O.; Aligbe, J.O.; Iruo, F.A.; Amadi, M.U.; Iheanacho, S.C.; Osuji, E.E.; Munonye, J.; Uwadoka, C. Climate change adaptation actions by fish farmers: Evidence from the Niger Delta Region of Nigeria. Aust. J. Agric. Resour. Econ. 2020, 59, 1-29. [CrossRef]

5. Rana, K.J.; Siriwardena, S.; Hasan, M.R. Impact of Rising Feed Ingredient Prices on Aquafeeds and Aquaculture Production; Fisheries and Aquaculture Technical Paper. No. 541; FAO: Rome, Italy, 2009.

6. FAO. The State of World Fisheries and Aquaculture 2018-Meeting the Sustainable Development Goals; FAO: Rome, Italy, 2018. Available online: http:/ / www.fao.org/documents/card/en/c/I9540EN/ (accessed on 16 July 2020).

7. Maiolo, S.; Parisi, G.; Biondi, N.; Lunelli, F.; Emilio, T.E.; Pastres, R. Fishmeal partial substitution within aquafeed formulations: Life cycle assessment of four alternative protein sources. Int. J. Life Cycle Assess. 2020. [CrossRef]

8. Thorarinsdottir, R.I.; Jokumsen, A.; Bjornsson, B.T.; Torrissen, O. Local Raw Materials for Production of Fish Feed for Aquaculture; Nordic Innovation Centre Project No. 10102; Norden: Oslo, Norway, 2011.

9. Gephart, J.A.; Golden, C.D.; Asche, F.; Belton, B.; Brugere, C.; Froehlich, H.E.; Fry, J.P.; Halpern, B.S.; Hicks, C.C.; Jones, R.C.; et al. Scenarios for global aquaculture and its role in human nutrition. Rev. Fish. Sci. Aquac. 2020. [CrossRef]

10. Wilfart, A.; Espagnol, S.; Dauguet, S.; Tailleur, A.; Gac, A.; Garcia-Launay, F. ECOALIM: A Dataset of Environmental Impacts of Feed Ingredients Used in French Animal Production. PLOS ONE 2016, 11, e0167343. [CrossRef] [PubMed]

11. The Danish National Bioeconomy Panel New Protein Value Chains-Recommendations to the Danish Government for the Proteins of the Future. Ministry of Environment and Food-Ministry of Environment and Food of Denmark. 2018. Available online: https://mfvm.dk/fileadmin/user_upload/MFVM/Miljoe/Biooekonomi/Recommendations_from_the_National_ Bioeconomy_Panel_Proteins_for_the_future_PDF_.pdf (accessed on 20 October 2020).

12. Iheanacho, S.C.; Ogueji, E.; Igberi, C.; Avwemoya, F.; Amadi-Eke, A.; Yaji, A.; Mbah, C. Suitability of discarded cashewnut meal (Anacardium occidentale L.) as replacement of soy bean meal (Glycine max) in the diet of juvenile African catfish Clarias gariepinus (Burchell, 1822). Indian J. Fish. 2019, 66, 78-86. [CrossRef]

13. Ogunji, J.O.; Iheanacho, S.C.; Abe, G.A.; Ikeh, O.R. Assessing effects of substituting dietary fish mea with Boiled Donkey and Cow Blood Meal on Growth Performance and Digestive Enzyme Activities of Clarias gariepinus Juvenile. J. World Aquac. Soc. 2020, 51, 1066-1079. [CrossRef]

14. Bio-Based Industries Consortium-BbIC. Biobased Industries Joint Undertaken: A £3.7 Billion Partnership between the European Union and the Bio-Based Industries Consotium. 2019. Available online: https://www.bbi-europe.eu/ (accessed on 20 October 2020).

15. Ogunji, J.O.; Wirth, M. Alternative protein sources as substitutes for fish meal in the diet of young Tilapia Oreochromis niloticus (Linn.). Isr. J. Aquac. Bamidgeh 2001, 53, 34-43.

16. Ogunji, J.O. Alternative Protein Sources in Diets for Farmed Tilapia; Animalscience.com Reviews No. 13; CAB International Publishing: Oxford, UK, 2004. Available online: https:/ / www.cabi.org/cabreviews/review/20053092365 (accessed on 21 January 2019).

17. Ogueji, E.; Iheanacho, S.C.; Mbah, C.; Yaji, A.J.; Ezemagu, U. Effect of partial and complete replacement of soybean with discarded cashew nut (Anacardium occidentale L.) on liver and stomach histology of Clarias gariepinus (Burchell, 1822). Aquac. Fish. 2020, 5, 86-91. [CrossRef]

18. FAO. The Effect of COVID-19 on Fisheries and Aquaculture in Asia. 2020. Available online: https://reliefweb.int/ sites/reliefweb. int/ files / resources/CA9545EN.pdf (accessed on 21 October 2020).

19. Nordic Council of Ministrers. Nordic Alternative Protein Potentials: Mapping of Regional Bioeconomy Opportunities. 2016. Available online: http:/ / www.diva-portal.org/smash/get/diva2:1033296/FULLTEXT02.pdf (accessed on 17 November 2020). [CrossRef]

20. Nordic Council of Ministers. Ten Trends for the Sustainable Bioeconomy in Nordic Arctic and Baltic Sea Region. 2020. Nordpub Copenhegan. Available online: https:/ / www.norden.org/en/publication/ten-trends-sustainable-bioeconomy-nordic-arcticand-baltic-sea-region-responsible (accessed on 15 January 2021). [CrossRef]

21. Bioeconomy Council. Bioeconomy for Sustainable Nutrition New Approaches to the Protein Supply of the Future. 2017, pp. 1-9. Available online: https://biooekonomierat.de/fileadmin/Publikationen/Englisch/BOERMEMO_final_english_1.pdf (accessed on 15 January 2021).

22. FAO. Species Fact Sheet-Clarias Gariepinus (Burchell, 1822) Clarias gariepinus. 2020. Available online: http://www.fao.org/ fishery/species/2982/en (accessed on 22 November 2020). 
23. William, B.B.; Olaosebikan, B.D.; Adeleke, A.; Fagbenro, O.A. Status of African catfish farming in Nigeria. In Proceedings of the Workshop on the Development of Genetic Improvement Program for African Catfish Clarias gariepinus, Accra, Ghana, 5-9 November 2007; pp. 49-56.

24. Fagbenro, O.A.; Adeparusi, E.O.; Jimoh, W.A. Haematological profile of blood of African Catfish (Clarias gariepinus Burchell, 1822) fed sunflower and sesame meal based diet. J. Fish. Aquat. Sci. 2013, 8, 80-86. [CrossRef]

25. Khan, F.; Khan, M.A. Growth, feed conversion, and nutrient retention efficiency of African Catfish, Clarias gariepinus, (Burchell, 1822) fingerling fed diets with varying levels of protein. J. Appl. Aquac. 2011, 23, 304-316.

26. Iheanacho, S.C.; Odo, G.E.; Ezewudo, B.I. Adulteration of Aquafeed with melamine and melamine-formaldehyde chemicals. Ex situ study of impact on haematology and antioxidant systems in Clarias gariepinus. Aquac. Res. 2020. [CrossRef]

27. Çek, S.; Yilmaz, E. The effect of varying dietary energy on gonad development at first sexual maturity of the sharptooth catfish (Clarias gariepinus Burchell, 1822). Aquac. Int. 2009, 17, 553-563. [CrossRef]

28. Balogun, A.M.; Fashakin, E.A. Replacement of groundnut cake with processed Soybean meals in diets for the African mud catfish, Clarias gariepinus. J. Appl. Trop. Agric. 1996, 1, 5-11.

29. Iheanacho, S.; Ikwo, T.; Igweze, N.; Chukwuidha, C.; Ogueji, E.; Onyeneke, R. Effect of different dietary inclusion levels of melon seed (Citrullus lanatus) peel on growth, Haematology and Histology of Oroechromis niloticus Juvenile. Turk. J. Fish. Aquat. Sci. 2018, 18, 377-384. [CrossRef]

30. Milton, J.; Bhat, A.A.; Haniffa, M.A.; Hussain, S.A.; Rather, I.A.; Al-Anazi, K.M.; Waleed Hailan, W.A.Q.; Farah, M.A. Ovarian development and histological observations of threatened dwarf snakehead fish, Channagachua (Hamilton, 1822). Saudi J. Biol. Sci. 2018, 25, 149-153. [CrossRef]

31. Idowu, E.O. Cyclical changes in the histology of the gonads (ovary and testes) of African pike. Hepsetusodoe. Afr. J. Biotechnol. 2017, 16, 1032-1041. [CrossRef]

32. Mandić, M.; Regner, S. Variation in fish egg size in several pelagic fish species. Study Mar. 2014, 27, 31-46.

33. Ogunji, J.O.; Kolas, W.; Wirth, M.; Schulz, C.; Rennert, B. Housefly maggot meal (magmeal) as a protein source for Oreochromis niloticus (Linn). Asian Fish. Sci. 2008, 21, 319-331.

34. Ogunji, J.O.; Nimpptsch, J.; Wiegand, C.; Schulz, C. Evaluation of the influence of housefly maggot meal (magmeal) diets on catalase, glutathione, s-transferase and glycogen concentration of the liver of Oreochromis niloticus fingerling. Comp. Biochem, Physiol. A 2007, 20, 942-947. [CrossRef]

35. Ajani, E.K.; Nwanna, I.C.; Musa, B.O. Replacement of fishmeal with maggot meal in the diets of Nile Tilapia Oreochronus niloticus. World Aquacult. 2004, 35, 52-54.

36. Idowu, A.B.; Amusan, A.A.S.; Oyediran, A.G. The response of fingerlings Clarias gariepinus (Burchell, 1822) to the diet containing Housefly maggot (Musca domestica). Niger. J. Anim. Prod. 2003, 30, 139-144. [CrossRef]

37. Fashina-Bombata, H.A.; Balogu, O. The effect of partial or total replacement of fish meal in the diet of tilapia (Oreochromisniloticus) fry. J. Prospect. Sci. 1997, 1, 178-181.

38. Kroeckel, S.; Harjes, A.G.E.; Roth, I.; Katz, H.; Wuertz, S.; Susenbeth, A.; Schulz, C. When a turbot catches a fly: Evaluation of a pre-pupae meal of the Black Soldier Fly (Hermetiaillucens) as fish meal substitute-Growth performance and chitin degradation in juvenile turbot (Psetta maxima). Aquaculture 2012, 364-365, 345-352. [CrossRef]

39. Bromage, N.R. Broodstockmanagement and seed quality. In Broodstock Management and Egg and Leaveae Quality; Bromage, N.R., Roberts, J., Eds.; Cambridge University Press: Cambridge, UK, 1995; pp. 1-24.

40. Adeyemi, J.A.; Klerrks, P.L. Occurrence of copper acclimation in the least killifish (Heterardria formosa) and associated biochemical and physiological mechanism. Aquat. Toxicol. 2013, 130, 1-57. [CrossRef]

41. Fasakin, E.A.; Balogun, A.M.; Ajayi, O.O. Evaluation of full-fat and defatted maggot meals in the feeding of Clariid catfish Clarias gariepinus fingerlings. Aquac. Res. 2003, 34, 733-738. [CrossRef]

42. Ogunji, J.O.; Nimptsch, J.; Wiegand, C.; Schulz, C.; Rennert, B. Effect of housefly maggot meal (magmeal) diets on catalase, and glutathione S-transferase in the liver and gills of carp Cyprinus carpio fingerling. Int. Aquat. Res. 2011, 2, 39-44.

43. Schulz, C.; Knaus, U.; Wirth, M.; Rennert, B. Effects of varying dietary fatty acid profile on growth performance, fatty acid, body and tissue composition of juvenile pike perch (Sander lucioperca). Aquac. Nutr. 2005, 11, 1-11. [CrossRef]

44. Iheanacho, S.C.; Odo, G.E. Dietary exposure to polyvinyl chloride microparticles induced oxidative stress and hepatic damage in Clarias gariepinus (Burchell, 1822). Environ. Sci. Pollut. Res. 2020, 27, 21159-21173. [CrossRef]

45. Copper, J.E.; Budgeon, C.R.; Foutz, C.A.; van Rossum, D.B.; Vansclow, D.J.; Hubley, M.J.; Clark, D.P.; Mandrell, D.T.; Cheng, K.C. Comparative analysis of fixation and embedding techniques for optimized histological preparation of zebrafish. Comp. Biochem. Physiol. 2018, 208, 38-46. [CrossRef]

46. Baker, F.J.; Silverton, C.J.; Palliste, C. Introduction to Medical Laboratory Technology; Hodder Arnold Publication: Los Angeles, CA, USA, 1989; p. 156.

47. FAO. North African Catfish-Clarias gariepinus (Burchell, 1822); FAO: Rome, Italy, 2014. Available online: http://www.fao.org/ fishery/affris/species-profiles/north-african-catfish/north-african-catfish-home/en/ (accessed on 12 September 2014).

48. Ali, M.Z.; Jauncey, K. Effects of feeding regime and dietary protein on growth and body composition in Clarias gariepinus (Burchell, 1822). Indian J. Fish 2004, 51, 407-416.

49. Ogunji, J.O.; Rahat-Ul-Ain, S.T.; Schulz, C.; Kloas, W. Growth performance, nutrient utilization of Nile tilapia, Oreochromis niloticus fed housefly maggot meal (magmeal) diets. Turk. J. Fish. Aquat. Sci. 2008, 8, 141-147. 
50. Ekanem, A.P.; Eteng, S.U.; Nwosu, F.M.; Eyo, V.O. Comparative study of the growth and gonad development of Clarias gariepinus (Burchell, 1822) fed diets with plant and animal-based ingredients in concrete tanks. J. Agric. Sci. Technol. 2012, 2, 1203-1210.

51. Alegbeleye, W.O.; Adetayo, J.A.; Ogunmoroti, T.A. Simple methods for off-season breeding. Aqabyte 1991, 4, 3-4.

52. Ogunji, J.O.; Kloas, W.; Wirth, M.; Neumann, N.; Pietsch, C. Effect of housefly maggot meal (magmeal) diets on the concentration plasma gluocose, cortisol and blood characteristics of Oreochromis niloticus fingerlings. J. Anim. Physiol. Anim. Nutr. 2008, 92, 511-518. [CrossRef] [PubMed]

53. Renna, M.A.; Schiavone, A.; Gai, F.; Dabbou, F.; Lussiana, C.; Malfatto, V.; Prearo, M.T.; Capucchio, M.T.; Biasato, I.; Biasibetti, E.; et al. Evaluation of the suitability of a partially defatted black soldier fly (Hermetiaillucens L.) larvae meal as ingredient for rainbow trout (IWalbaum) diets. J. Anim. Sci. Biotechnol. 2017, 8, 57. [CrossRef] [PubMed]

54. Hashemi, S.; Kashi, M.; Safikhani, H. Growth parameter, Length-Weight relationship and quality coefficient of klunzingeri Mullet (Liza klunzingeri (Day, 1888)) in the Coastal of Khuzestan (Northwest of Persian Gulf). J. Nov. Appl. Sci. 2013, 2, 60-64.

55. Al-Deghayem, W.A.; Al-Balawi, H.F.; Kandeal, S.A.; Suliman, E.A. Gonadosomatic index and some hematological parameters in African catfish Clarias gariepinus (Burchell, 1822) as affected by feed type and temperature level. Braz. Arch. Biol. Technol. 2017, 60, 1-10. [CrossRef]

56. Cek, S.; Bromage, N.R.; Randall, C.; Rana, K. Ogenesis hepatosomatic indexes, and sex ration in Rosy in rosy barb (Pontius conchonius). Turk. J. Fish Aquat. Sci. 2001, 1, 133-141.

57. Anibueze, C.I.P.; Inyang, N.M. Oocytes Structure, fecundity and sex Ratio of Heterobranchuslongifilis (Valenciennes 1840) in Idodo River Basin (Nigeria) with Comments on the Breding Biology. J. Aquat. Sci. 2003, 15, 59-62.

58. Arockiaraji, A.J.; Haniffa, M.A.; Seetharaman, S.; Singh, S. Cyclic Changes in gonadal maturation and histological observations of threatened freshwater catfish. "Narikeliru” MystusMonthanus (Jerdon, 1849). Acta. Ichthyol. Piscat. 2004, 34, 253-266. [CrossRef]

59. Olaleye, V.F. A review of reproduction and gamete management in the African catfish Clarias gariepinus. Life J. Sci. 2005, 7, 63-70. [CrossRef]

60. Jalabert, B. Particularities of reproduction and oogenesis in teleost fish compared to mammals. Reprod. Nutr. Dev. 2005, 45, 261-279. [CrossRef] [PubMed]

61. Gupta, S. The development of carp gonads in warm water aquaria. J. Fish Biol. 1975, 7, 775-782. [CrossRef]

62. Bromage, N.R.; Cumaranatunga, P.R.T. Oocytes development in the rainbow trout with special reference to vitellogenesis and artresia. In Proceedings of the 3rd International Symposium on the Reproductive Physiology of Fish, St. John's, NL, Canada, 2-7 August 1987; Idler, D.R., Crin, L.W., Walsh, J.M., Eds.; Marine Sciences Research Laboratory, Memorial University of Newfoundland: St John's, NL, Canada, 1987; p. 194.

63. Çek, S.; Yilmaz, E. Gonadal development and sex ratio of shaptooth catfish (Clarias gariepinus Burchel, 1822) cultured under laboratory conditions. Turk. J. Zool. 2007, 31, 35-46.

64. Ogunji, J.O.; Rahe, R.E. Larval development of the African catfish Heterobranchus longifilis val., 1840 (Teleostei; Clariidae) and its larval behaviour. J. Aquac. Trop. 1999, 14, 11-25.

65. Guraya, S.S. The biology of gonadal development, sex differentiation and maturation and sex reversal in fish: Cellular, molecular and endocrinological aspects. Proc. Indian Nat. Sci. Acad. 2000, 66, 167-194.

66. Schulz, R.W.; Vander Corput, L.; Janssen-Dommerholt, J.; Goos, H.J. Sexual steroids during puberty in male African Catfish (Clarias gariepinus): Serum levels and gonadototropin stimulated tesicular secretion in vitro. J. Comp. Physiol. Biol. 1994, 164, 195-205. [CrossRef]

67. Kurbanov, A.; Kamilov, B. Maturation of African catfish, Clarias gariepinus, in condition of seasonal climate of Uzbekistan. Int. J. Fish. Aquat. Stud. 2017, 5, 236-239. 